\title{
ANALISIS FAKTOR YANG BERHUBUNGAN DENGAN KEJADIAN DIARE PADA BALITA DI PUSKESMAS KEDATON KOTA BANDAR LAMPUNG
}

\author{
Asa Izati ${ }^{1}$, Dwijowati Asih Saputri ${ }^{2}$, Marlina Kamelia², Nurhaida Widiani² \\ ${ }^{1}$ Alumni Program Studi Pendidikan Biologi, Fakultas Tarbiyah dan Keguruan, UIN \\ Raden Intan Lampung, Lampung, Indonesia \\ 2 Program Studi Pendidikan Biologi, Fakultas Tarbiyah dan Keguruan, UIN Raden \\ Intan Lampung, Lampung, Indonesia
}

\begin{abstract}
Analysis of Factors That are Related to The Event of Diarrhea in Children in Kedaton Health Center of Bandar Lampung City. The incidence of diarrhea in infants in Bandar Lampung is still quite high in 2016. The highest case occurred in the Kedaton Health Center. Environmental sanitation and family conditions are thought to affect diarrhea cases. This study aims to determine the factors associated with the incidence of diarrhea in infants at the Kedaton Health Center, Bandar Lampung. This type of research is observational analytic using cross sectional study approach. Laboratory test results show that most microbes that infect infants in the Kedaton health center, Bandar Lampung are bacilli and gramnegative. Although it is also found that the microbes are cocci and gram-positive. Environmental sanitation and family conditions (age and type of work of the mother) affect the incidence of diarrhea in infants at the Kedaton health center, Bandar Lampung.
\end{abstract}

Keywords : diarrhea, microbes, environmental sanitation

\begin{abstract}
Abstrak: Analisis Faktor yang Berhubungan dengan Kejadian Diare pada Balita di Puskesmas Kedaton Kota Bandar Lampung. Angka kejadian diare pada balita di Bandar Lampung masih cukup tinggi pada tahun 2016. Kasus tertinggi ditemukan di puskesmas Kedaton Bandar Lampung. Sanitasi lingkungan dan kondisi keluarga diduga dapat mempengaruhi kasus diare. Penelitian ini bertujuan untuk mengetahui faktor-faktor yang berhubungan dengan kejadian diare pada balita di Puskesmas Kedaton, Bandar Lampung. Jenis penelitian ini merupakan penelitian analitik observasional dengan menggunakan pendekatan cross sectional study. Hasil uji laboratorium menunjukkan bahwa sebagian besar mikroba yang menginfeksi balita di puskesmas Kedaton, Bandar Lampung berbentuk basil/batang dan bersifat gram negatif. Meskipun juga ditemukan mikroba berbentuk bulat/kokus dan bersifat gram positif. Sanitasi lingkungan dan kondisi keluarga (usia dan jenis pekerjaan ibu) mempengaruhi angka kejadian diare pada balita di puskesmas Kedaton, Bandar lampung.
\end{abstract}

Kata Kunci : Diare, Mikroba, Sanitasi Lingkungan

\section{PENDAHULUAN}

Salah satu masalah kesehatan yang masih sering terjadi di negara berkembang seperti Indonesia adalah diare. Penyakit ini merupakan penyakit menular yang disebabkan oleh virus, bakteri, dan parasit. Diare merupakan penyakit gangguan pencernaan yang sering disebabkan adanya infeksi oleh mikroorganisme. Mikroba yang menjadi penyebab penyakit ini adalah Rotavirus, Escherichia coli, Shighella, Campylobacter jejuni, Vibrio cholerae, Salmonella sp (non tifoid), Yersinia sp, Vibrio para haemolyticus, Giardia lamblia, Entamoeba histolytica, dan Cryptosporidium. Selain itu makanan, alergi dan malnutrisi juga dapat menjadi pemicu terjadinya diare (Depkes RI, 1990). Makanan dan 
minuman yang terkontaminasi tinja atau muntahan yang didalamnya terkandung kuman (virus, bakteri, dan parasit) dapat menyebabkan diare (Kusbaryanto dan Tatik, 2008).

Kasus diare sering berhubungan dengan sanitasi lingkungan yang buruk dan sumber air bersih yang belum mencukupi standar kesehatan. Berdasarkan penelitian Amaliah (2010), terdapat hubungan antara penggunaan air bersih, kepemilikan jamban, penggunaan air minum, kebiasaan $B A B$, kebiasaan cuci tangan dengan sabun dan penanganan diare dengan kejadian diare. Kondisi keluarga dan tingkat pemahaman ibu juga dapat menjadi faktor yang berhubungan dengan diare. Penelitian yang dilakukan oleh Nurpauji (2015) menunjukan bahwa jenis sumber air untuk minum dan perilaku ibu dalam mengelola makanan dan minuman dapat berpengaruh terhadap tingginya angka diare pada balita di puskesmas Lamper Semarang.

$$
\text { Berdasarkan data Riset }
$$

Kesehatan Dasar (Riskesdas) period prevalence diare di Indonesia tahun 2013 (sebesar 3,5\%) lebih kecil dibandingkan tahun 2007 (sebanyak 9\%). Prevalensi diare di Indonesia pada usia $>15$ tahun adalah sebanyak $30,1 \%$, sedangkan prevalensi diare pada usia <15 tahun sebanyak 21,9\% (Fatkhur, et al., 2016). Angka kejadian diare pada balita di Kota Bandar Lampung tahun 2016 sebanyak 6855 balita. Angka kejadian diare tertinggi terjadi di Puskesmas Kedaton yaitu sebanyak 666 balita dan angka terendah terjadi di Puskesmas Korpri yaitu 35 balita (Dinkes Kota Bandar Lampung, 2016). Setiap tahunnya angka kejadian diare terus bertambah. Oleh karenanya, peneliti tertarik meneliti faktor-faktor yang berhubungan dengan kejadian diare pada balita di puskesmas Kedaton, Bandar Lampung.

\section{METODE PENELITIAN}

Penelitian dilaksanakan pada bulan Agustus - September tahun 2017. Jenis penelitian ini adalah penelitian analitik observasional dengan menggunakan pendekatan cross sectional study.

Populasi penelitian adalah balita diare yang diambil dari Puskesmas Kedaton Kota Bandar Lampung. Kemudian dianalisis di UPTD Balai Laboratorium Kesehatan Provinsi Lampung.

Pengambilan sampel dengan teknik purposive sampling. Sampel penelitian ialah anak balita usia 0,5 tahun yang mengalami diare dan sebagai responden yaitu ibu yang memiliki balita usia 0-5 tahun. Total sampelnya 30 balita.

Kriteria inklusi dan eksklusi dalam menentukan sampel penelitian adalah sebagai berikut :

a. Kriteria Inklusi :

$\checkmark$ Terdaftar sebagai pasien yang menderita diare di Puskesmas Kedaton Kota Bandar Lampung.

$\checkmark$ Bersedia menjadi responden.

$\checkmark$ Bersedia saat pelaksanaan pengambilan sampel.

$\checkmark$ Berusia 0-5 Tahun.

b. Kriteria Eksklusi :

$\checkmark$ Tidak terdaftar sebagai pasien yang menderita diare di Puskesmas Kedaton Kota Bandar Lampung.

$\checkmark$ Tidak bersedia menjadi responden.

$\checkmark$ Tidak bersedia saat pelaksanaan pengambilan sampel.

$\checkmark$ Berusia lebih dari 0-5 Tahun.

Data primer penelitian berupa data identitas subjek dan responden, data berat badan balita, data mengenai sanitasi lingkungan rumah, dan untuk pemeriksaan mikroba, feses balita terduga diare dianalisis di laboratorium. Sedangkan data sekunder yang meliputi: gambaran umum wilayah penelitian dan data rekam medis Puskesmas Kedaton Kota Bandar Lampung mengenai balita yang mengalami diare.

\section{HASIL}

Hasil pemeriksaan feses balita penderita diare di puskesmas Kedaton Bandar lampung menunjukkan adanya investasi mikroba dengan bentuk dan 
sifat yang berbeda-beda. Bentuk mikroba Sampel feses dari 30 balita penderita diare di puskesmas kedaton
Bandar lampung tertera pada tabel berikut:

Tabel 1. Investasi mikroba pada balita penderita diare di Puskesmas Kedaton Bandar Lampung berdasarkan bentuk sel

\begin{tabular}{clccc}
\hline \multirow{2}{*}{ No } & \multirow{2}{*}{ Bentuk Mikroba } & \multicolumn{2}{c}{ Jenis Kelamin } & \multirow{2}{*}{$\%$} \\
\cline { 3 - 4 } & & $\mathbf{L}$ & $\mathbf{P}$ & $\%$ \\
\cline { 1 - 3 } 1 & Basil/batang & 18 & 12 & $54,55 \%$ \\
2 & Kokus/bulat & 14 & 11 & $45,45 \%$ \\
\hline
\end{tabular}

Dari tabel tersebut dapat dilihat bahwa mikroba berbentuk basil lebih banyak ditemukan dibandingkan yang

\section{a. Sifat Mikroba}

Salah satu sifat mikroba adalah gram. Sifat bakteri ini bisa diketahui dengan melakukan pengecatan gram. Ada 2 sifat bakteri berdasarkan pewarnaan gram, yaitu gram negatif dan gram positif. Bakteri gram negatif akan terlihat berwarna merah, sementara bakteri dengan sifat gram berbentuk kokus, baik pada balita lakilaki ataupun perempuan.

positif akan berwarna ungu atau violet. Hasil pengamatan terhadap feses balita penderita diare menunjukkan bahwa bakteri yang ditemukan ada yang memiliki sifat gram negatif maupun gram positif. Hasil pengamatan sifat gram bakteri disajikan pada tabel 2 berikut:

Tabel 2. Investasi mikroba pada balita penderita diare di Puskesmas Kedaton Bandar Lampung berdasarkan sifat sel

\begin{tabular}{ccccc}
\hline \multirow{2}{*}{ No } & \multirow{2}{*}{ Sifat Mikroba } & \multicolumn{2}{c}{ Jenis Kelamin } & \\
\cline { 3 - 4 } & & $\mathbf{L}$ & $\mathbf{P}$ & \\
\cline { 1 - 3 } 1 & Gram positif & 9 & 3 & $28,57 \%$ \\
2 & Gram negatif & 19 & 11 & $71,43 \%$ \\
\hline
\end{tabular}

Dari tabel diatas bisa dilihat bahwa balita baik laki-laki ataupun perempuan lebih banyak yang terserang bakteri

\section{b. Usia Balita}

Balita yang menjadi sampel pada penelitian ini dikelompokkan menjadi 3. Kelompok 1, balita dengan usia kurang dari 1 tahun, kelompok 2, balita antara 1-3 tahun, dan kelompok 3 adalah balita dengan umur lebih dari 3 tahun. gram negatif jika dibandingkan dengan bakteri gram positif.

Hasil penelitian menunjukkan bahwa terdapat perbedaan investasi mikroba pada 3 kelompok umur tersebut. Secara rinci, hasil penelitian terhadap investasi mikroba berdasarkan umur balita disajikan pada tabel 3. 
Tabel 3. Investasi mikroba pada balita penderita diare di Puskesmas Kedaton Bandar Lampung berdasarkan usia

\begin{tabular}{llcccc}
\hline \multirow{2}{*}{ No } & \multirow{2}{*}{ Sifat Mikroba } & \multicolumn{3}{c}{ Balita Penderita Diare } \\
\cline { 3 - 6 } & & \multicolumn{2}{c}{ Laki laki } & \multicolumn{2}{c}{ Perempuan } \\
\cline { 3 - 6 } & & $\Sigma$ & $\%$ & $\Sigma$ & $\%$ \\
\cline { 3 - 6 } 1 & $<1$ tahun & 3 & 10 & 0 & 0 \\
2 & $1-3$ tahun & 11 & 36.67 & 6 & 20 \\
3 & $>3$ tahun & 4 & 13.33 & 6 & 20 \\
\hline
\end{tabular}

\section{d. Kondisi Keluarga}

Kondisi Keluarga yang diamati dalam penelitian ini meliputi umur dan pekerjaan orang tua balita. Hasil kuisioner yang diberikan kepada orang tua balita penderita diare di Puskesmas Kedaton Bandar Lampung tertera pada tabel 4.

Tabel 4. Investasi mikroba pada balita penderita diare di Puskesmas Kedaton Bandar Lampung berdasarkan kondisi keluarga

\begin{tabular}{|c|c|c|c|c|c|}
\hline \multirow{3}{*}{ No } & \multirow{3}{*}{ Kondisi orang tua } & \multicolumn{4}{|c|}{ Balita Penderita Diare } \\
\hline & & \multicolumn{2}{|c|}{ Laki laki } & \multicolumn{2}{|c|}{ Perempuan } \\
\hline & & $\Sigma$ & $\%$ & $\Sigma$ & $\%$ \\
\hline \multirow{3}{*}{1} & UMUR (Tahun) & & & & \\
\hline & $20-35$ & 11 & 36.67 & 10 & 33.33 \\
\hline & $>35$ & 7 & 23.33 & 2 & 6.67 \\
\hline \multirow{6}{*}{2} & Pekerjaan & & & & \\
\hline & PNS & 0 & 0 & 2 & 6.67 \\
\hline & Wiraswasta & 1 & 3.33 & 1 & 3.33 \\
\hline & Karyawan Swasta & 5 & 16.67 & 2 & 6.67 \\
\hline & Ibu Rumah Tangga & 11 & 36.67 & 5 & 16.67 \\
\hline & Buruh & 1 & 3.33 & 2 & 6.66 \\
\hline \multirow{5}{*}{3} & Pendidikan & & & & \\
\hline & SD & 4 & 13.33 & 0 & 0 \\
\hline & SMP & 0 & 0 & 2 & 6.67 \\
\hline & SLTA & 8 & 26.67 & 6 & 20 \\
\hline & Perguruan tinggi & 6 & 20 & 4 & 13.33 \\
\hline
\end{tabular}

\section{e. Sanitasi}

Hasil uji statistik antara sanitasi lingkungan dan investasi mikroba pada balita penderita diare di puskesmas
Kedaton Kota Bandar Lampung dapat dilihat pada tabel 5 berikut: 
Tabel 5. Hubungan antara sanitasi lingkungan dan Investasi mikroba balita Penderita Diare di Puskesmas Kedaton Bandar Lampung.

\begin{tabular}{|c|c|c|c|c|c|c|c|}
\hline \multirow{3}{*}{ Sanitasi Lingkungan } & \multicolumn{4}{|c|}{ Investasi Mikroba } & \multirow{2}{*}{\multicolumn{2}{|c|}{ Total }} & \multirow{3}{*}{$\begin{array}{c}\text { Nilai } \\
\mathbf{P}\end{array}$} \\
\hline & \multicolumn{2}{|r|}{$\mathbf{L}$} & \multicolumn{2}{|c|}{$\mathbf{P}$} & & & \\
\hline & $\Sigma$ & $\%$ & $\Sigma$ & $\%$ & $\Sigma$ & $\%$ & \\
\hline \multicolumn{8}{|l|}{ Sumber Air Minum } \\
\hline Terlindung & 6 & 20 & 1 & 3.33 & 7 & 23.3 & \multirow{2}{*}{0.003} \\
\hline Tidak Terlindung & 12 & 43.33 & 11 & 36.7 & 23 & 76.7 & \\
\hline \multicolumn{8}{|l|}{ Kualitas Fisik Air Bersih } \\
\hline memenuhi syarat & 9 & 30 & 6 & 20 & 15 & 50 & \multirow{2}{*}{0.00} \\
\hline tidak memenuhi syarat & 9 & 30 & 6 & 20 & 15 & 50 & \\
\hline \multicolumn{8}{|l|}{ Kepemilikan Jamban } \\
\hline Memiliki & 4 & 13.33 & 7 & 23.3 & 11 & 36.7 & \multirow{2}{*}{0.144} \\
\hline tidak memiliki & 14 & 46.67 & 5 & 16.7 & 19 & 63.3 & \\
\hline \multicolumn{8}{|l|}{ Lantai Rumah } \\
\hline Kedap Air & 18 & 60 & 12 & 40 & 30 & 100 & \\
\hline Tidak Kedap Air & 0 & & 0 & 0 & 0 & 0 & \\
\hline
\end{tabular}

\section{PEMBAHASAN}

Diare merupakan gangguan pencernaan yang ditandai dengan meningkatnya frekuensi buang air besar. Munculnya diare sering dihubungkan dengan adanya infeksi pada saluran pencernaan oleh berbagai macam organisme, diantaranya adalah bakteri. Ada 4 macam bakteri yang umum menyebabkan diare, yaitu Escherichia coli, Salmonella enteritica, Shigella dan Campylobacter jejuni (Alodokter, 2019). Menurut Tantri (2016), E. Coli memiliki bentuk batang atau basil, Salmonella mempunyai bentuk batang, Shigella juga mempunyai bentuk batang, sedangkan Campilobacter jejuni memiliki bentuk spirillum (menyerupai batang) jika dilihat dengan mikroskop cahaya (Andriani, dkk. 2013). Ke empat bakteri tersebut merupakan bakteri gram negatif (Tantri, 2016). Hasil penelitian Pramana dkk. (2014) pada balita penderita diare di RSUP PROF. DR. R.D. Kadau Menado menunjukkan bahwa ditemukan juga bakteri yang memiliki sifat gram positif pada penderita diare.
Hal ini sejalan dengan penelitian yang dilakukan pada balita di puskesmas kedaton. Dari hasil analisis laboratorium diduga penyebab diare pada balita di puskesmas Kedaton disebabkan oleh bakteri.

Tabel 3 menunjukan bahwa investasi bakteri tertinggi pada balita usia antara 1-3 tahun sesuai dengan data yang dikeluarkan oleh WHO, yaitu $80 \%$ penderita diare adalah balita terutama di bawah 5 tahun (Simadibrata, 2011). Prevalensi diare juga sedikit lebih tinggi pada balita laki-laki, dibanding balita perempuan (Adisasmito, 2007 dan Kementerian Kesehatan, 2011). Hasil penelitian yang dilakukan juga menunjukan hal yang sama yaitu jumlah investasi mikroba penyebab diare pada balita laki-laki lebih tinggi dibandingkan balita perempuan pada semua kelompok umur.

Dugaan yang bisa diambil dari hasil penelitian ini adalah balita pada umur tersebut (1 - 3 tahun) sudah mulai aktif bermain sehingga rentan terinfeksi bakteri. Selain itu, usia sapih 
balita terdapat pada rentang umur balita diberi lebih banyak makanan tambahan dan susu formula (minuman) sebagai pelengkap nutrisi balita. Jika pemberian susu formula dan makanan tambahan kurang memperhatikan kebersihan atau higienitas, maka balita di usia tersebut sangat rentan terhadap infeksi bakteri (Widoyono, 2011).

Hasil penelitian pada tabel 4 menunjukan bahwa keluarga dengan usia ibu yang cukup muda (20 - 35) tahun menunjukan kejadian diare pada balita lebih tinggi dibandingkan pada keluarga dengan usia ibu diatas 35 tahun. Keluarga dengan ibu berusia lebih muda kemungkinan belum memiliki pengalaman yang cukup untuk mengurus keluarga termasuk dalam hal perawatan anak. Usia ibu ternyata berpengaruh terhadap infeksi bakteri pada balita. Menurut Khusna dan Nuryanto (2017) adanya hubungan antara usia ibu dengan status gizi balita. Status gizi yang baik akan menentukan tumbuh kembang balita dan tingkat kesehatan balita, yang pada akhirnya akan mempengaruhi daya tahan tubuh balita terhadap infeksi bakteri. Maryana (2008) juga menjelaskan bahwa pengalaman ibu dalam mengasuh anak berhubungan dengan usia ibu, ibu yang berusia lebih dewasa memiliki pengalaman yang lebih banyak dalam pola asuh anak anaknya. Semakin dewasa seorang ibu, maka seorang ibu akan berfikir lebih cermat dan mempunyai pengalaman yang lebih banyak untuk diterapkan dalam mengasuh anak-anaknya sehingga kesehatan balitanya lebih baik.

Pekerjaan ibu juga mempengaruhi kejadian diare pada balita di puskesmas kedaton. Ibu rumah tangga memiliki waktu lebih banyak untuk memperhatikan kesehatan anak balitanya. Dari hasil penelitian menunjukan juga bahwa tidak ada korelasi antara pendidikan ibu dan kejadian diare pada pasien balita di Puskesmas tersebut.

Hasil penelitian untuk sanitas lingkungan disajikan pada tabel 5. Dari tersebut. Pasca penyapihan umumnya Tabel tersebut dapat dilihat bahwa jumlah Responden yang memiliki sumber air terlindung, angka kejadian diare lebih kecil dibandingkan balita dengan sumur tidak terlindung. Hasil analisis statistik juga menunjukan adanya korelasi ( $p=0,003$ ) antara sumber air minum dan kejadian diare pada balita di Puskesmas Kedaton Bandar Lampung. Kualitas fisik air memiliki korelasi yang sama besar terhadap investasi mikroba pada balita, yaitu $50 \%$ untuk kualitas fisik yang memenuhi syarat dan $50 \%$ untuk kualitas fisik air yang memenuhi syarat. Dalam hal kepemilikan jamban, tidak ada korelasi $(p=0,144)$ dengan kejadian diare pada balita di wilayah Puskesmas Kedaton Bandar Lampung. Semua responden pada penelitian ini memiliki lantai rumah yang kedap air. Semua balita yang menderita diare di Puskesmas kedaton Bandar Lampung, baik balita laki laki maupun perempuan telah memiliki lantai rumah yang kedap air.

\section{KESIMPULAN}

Berdasarkan penelitian yang telah dilakukan dapat disimpulkan bahwa kejadian diare pada balita di Puskesmas Kedaton, Bandar Lampung dipengaruhi oleh sanitasi lingkungan dan kondisi keluarga yang meliputi usia dan pekerjaan ibu. Hasil uji laboratorium juga menunjukan bahwa investasi mikroba penyebab diare juga berkorelasi dengan kejadian diare.

\section{DAFTAR PUSTAKA}

Adisamito W. 2007. Faktor resiko diare pada bayi dan Balita di Indonesia. Majalah Kesehatan. Vol 11: 1-10

Amaliah, S. 2010. Hubungan Sanitasi Lingkungan dan Faktor Budaya dengan Kejadian Diare pada Anak Balita di Desa Toriyo Kecamatan Bendosari Kabupaten Sukoharjo. Prosiding Seminar Nasional Unimus. HIm 91 - 97. http://jurnal.unimus.ac.id 
Andriani, Mirnawati, S., Surachmi, S., Hasni, D.K. 2013. Isolasi Campylobacter dari Karkas Ayam Menggunakan metode konvensional dan Polymerase Chain Reaction. J. Teknol, dan Industri Pangan. Vol 24 (1): 2732

Depkes RI, 1990. Pendidikan Medik Pemberantasan Diare, Buku Ajar Diare, Ditjen PPM-PLP, Jakarta.

Dinas Kesehatan Kota Bandar Lampung, 2016, Profil Kesehatan Kota Bandar Lampung Tahun 2016, Bandar Lampung.

Fatkhur, Handono Rahman, Slamet Widoyo, Heri Siswanto, Biantoro, 2016, Faktor-Faktor Yang Berhubungan Dengan Kejadian Diare Di Desa Solor Kecamatan Cermee Bondowoso, (Jurnal STIKes Nurul Jadid Paiton Probolinggo, NurseLine Journal Vol. 1 No. 1 Mei 2016 ISSN 2540-7937), hlm. 25.

Kementrian Kesehatan RI. 2011. Data dan Informasi Kesehatan.

Khusna, NA dan Nuryanto. 2017. Hubungan usia Ibu menikah Dengan Status Gizi Balita di Kabupaten Temanggung. Journal Of Nitrition College. 6(1): 1-10.

Kusbaryanto dan T. Hidayati, 2008, Gambaran Kejadian Wabah Diare dan Faktor-faktorTerkait di Dusun Senden Desa Sidorejo Kecamatan Lendah Kabupaten Kulon Progo tahun 2005, (Jurnal Mutiara Medika Vol.8 No.1: 0918 Januari 2008), hlm. 10.

Maryana, IU. 2008. Perilaku hidup Bersih dan Sehat, pengetahuan Gizi dan Pola Asuh Kaitannya dengan Diare Anak Balita, di Desa Cikarawang Bogor. Skripsi Mahasiswa Program
Nurpauji, S. V., 2015. Hubungan Jenis Sumber Air, Kualitas Bakteriologis Air, Personal Higiene Dengan Kejadian DIare Pada Balita di Wilayah Kerja Puskesmas Lamper Tengah Semarang. Jurnal Kesehatan Masyarakat FKM Undip Vol. 3 (2).

Studi Gizi Masyarakat dan Sumberdaya Keluarga Fakultas Pertanian Institut Pertanian Bogor. h. 23.

Pramana, I.M.D., Jeanette M. dan Rocky W. 2014. Pola Kuman Berdasarkan Pewarnaan Gram pada Anak dengan Diare di RSUP PROF. DR. R.D. Kandau Menado. Jurnal E-Clinic (ECL). Vol. 2 (1): 1-8.

Simadibrata M. ,Rani A., Syam AF. 2011. Pendekatan dan Penatalaksanaan diare akut. Buku Ajar Gastroenterologi, Eds. I. Interna Publishing . Jakarta Pusat. H. 67.

Tantri, B.U.N. 2016. Identifikasi bakteri E.coli, Shigella sp dan Salmonella sp. Pada air sumur di wilayah pembuangan Limbah Tahu dan Limbah Ikan Kota Bandar Lampung. SKRIPSI. Fakultas Kedokteran Universitas Lampung. Bandar Lampung.

Waqidil H dan Adini CK, 2016, Hubungan antara Tingkat Pendidikan Ibu dengan Perkembangan balita usia 3-5 tahun. Asuhan Kesehatan. 7(2):27-31.

Waspadai Bakteri Penyebab Diare. Alodokter. 5 Oktober 2019. Alodoker .com. Ditinjau oleh: dr. Merry Dame Cristi Pane. Diakses pada tanggal 5 Desember 2019.

Widoyono. 2011. Penyakit Tropis Epidemiologi Penularan, Pencegahan dan Pemberantasan $\left(2^{\text {nd }}\right.$ Ed.). Erlangga. Jakarta. 